\title{
Hydrography of Gourikere pond of Siddapur, Karnataka
}

\author{
V. Kumar. B $^{1 *}$ Roopa S.V ${ }^{2}$ and B.K. Gangadhar ${ }^{1}$ \\ 1- Department of studies in Zoology, Government Arts \&Science College, Karwar- 581303, India \\ 2- Department of Studies and Research in Marine Biology, Karnataka University P.G Centre, Kodibag, \\ Karwar-581303, India \\ * e-mail: bagalwad@rediffmail.com
}

\begin{abstract}
Present work was pertaining to studies conducted at one lentic perinial water body at Talaguppa viz., Gourikere pond Tq:Sagar Karnataka. The period of study undertaken it one year from May - 2007 to April - 2008. This study is intended to monitor the water quality of Gourikere pond of Talaguppa, Sagar Tq: Shimoga District and also helpful for using this water for making fisheries activity. The present investigation encompassed collection of data pertaining to various aspects such as meteorological condition, physicochemical parameter of water body of Gourikere pond. Air and surface water temperatures varied from $29.7^{\circ} \mathrm{C}$ to $37.5^{\circ} \mathrm{C}$ and from $20.6^{\circ} \mathrm{C}-24.8^{\circ} \mathrm{C}$. And the $\mathrm{pH}$ ranged between 8.1 to 9.1. Variation in dissolved oxygen content was from $6.4 \mathrm{mg} / \mathrm{l}$ to $10.8 \mathrm{mg} / \mathrm{l}$ and variation in $\mathrm{CO}_{2}$ was observed from $7.4 \mathrm{mg} / \mathrm{l}$ to $12.00 \mathrm{mg} / \mathrm{l}$. Concentrations of nutrients viz. nitrates $(0.69 \mathrm{mg} / \mathrm{l}$ to $1.30 \mathrm{mg} / \mathrm{l})$, phosphates $(0.30 \mathrm{mg} / \mathrm{l}$ to $0.63 \mathrm{mg} / \mathrm{l})$ Magnesium $(11.79 \mathrm{mg} / \mathrm{l}$ to $88.64 \mathrm{mg} / \mathrm{l})$ sulphate $(2.45 \mathrm{mg} / \mathrm{l}$ to 5.16 $\mathrm{mg} / \mathrm{l}$ ) Calcium (33.41 to $138.10 \mathrm{mg} / \mathrm{l}$ ), also varied independently. The results of the study revealed that hydrographical conditions fluctuated moderately throughout the year.
\end{abstract}

Keywords: Physico-chemical parameters, lentic, Nutrients, Gourikere pond.

\section{Introduction}

Present work was pertaining to studies conducted at lentic perinial water body at Talaguppa viz., Gourikere pond. The period of study undertaken it one year from May - 2007 to April - 2008. Gourikere is situated in the southern part of Karnataka state located 566 meters above the mean sea level. Its revenue taluk is Sagar \& revenue District is Shimoga. The temperature ranging between $19.13^{\circ} \mathrm{Cto}$ $37^{\circ} \mathrm{C}$. The average range for of Sagar taluk is $812 \mathrm{~mm}$ during 2008 , ranging $60.31 \%$. This area typically has an undulating contour thus making scope for depression and attachment areas there by numerous small ponds often loosely termed as tanks are common sight in this area.

The climate of Talaguppa is generally healthy and moderate. Presently one water body is selected at Talaguppa village. The hydrobiological investigations were limited primarily in the Gourikere pond with a view to understand the ecobiology of water bodies in details water body is known to be utilized for fisheries activity and at the same time dumping sink of for the agricultural waste. However, this pond is 
Sustainability, Agri, Food and Environmental Research 1(1): 1-7; 2013

ISSN: 0719-3726

mesotrophic. And present study of various physicochemical parameters of Gourikere pond were made to establish to know the safe for fisheries.

\section{Materials and methods}

The information regarding various climatic factors such as total rainfall, atmospheric temperature, humidity, obtained from meteorological centre, Sagar taluk for the period from May - 2007 to April 2008. However present study only rainfall data have been refereed. Water samples were collected on monthly basis from Gourikere pond Surface water samples were collected using clean BOD bottles for the study of various physicochemical parameter. Collection were made from six station in the Gourikere pond. All collections and observations were made between 08.30 to 10.30 am throughout the period of study.A separate samples were collected for the estimation of dissolved oxygen taking all the precautions and they were fixed in the field by adding reagents. All the samples were kept in the ice box and transported to the laboratory. After returning to the laboratory they were analyzed for various physico-chemical parameters by the standard methods given in APHA 1995.

\section{Results and discussion}

The present study can be divided into 3 distinct seasons such as southwest (June - September) North east (October - January), summer (February - May).

Total Rainfall: Total rainfall of the study area during study period between May 2007 to April 2008 was $3418.5 \mathrm{~mm}$ (Fig 1). Rainfall ranged between $9.8 \mathrm{~mm}$ and $1024.5 \mathrm{~mm}$ and rain did not occur during month of January 2008. Highest rainfall recorded during month of August 2007 i.e $1024.5 \mathrm{~mm}$ lowest during April 2008 i.e $9.8 \mathrm{~mm}$. The data pertaining to the rainfall during different seasons are presented in Fig 1 . In the present study, the peak values of rainfall were recorded during the South west monsoon month of (June - sept) and less in north east monsoon.

Atmospheric Temperature: The monthly variations in the atmospheric temperature during sample season of 2007 (Fig 2). The atmospheric temperature varied between $29.7^{\circ} \mathrm{C}$ to $37.5^{\circ} \mathrm{C}$. During north east monsoon season of $2007-08$ the atmospheric temperature $22.7^{\circ} \mathrm{C}$ to $29.8^{\circ} \mathrm{C}$, while the atmosphere temperature during south west monsoon of $2007-08$ ranged between $29.0^{\circ} \mathrm{C}$ to $37.5^{\circ} \mathrm{C}$.

Water Temperature: monthly variation in the water temperature are given in the Fig.3. During north east monsoon of $2007-08$ the water temperature $20.6^{\circ} \mathrm{C}-24.8^{\circ} \mathrm{C}$. While water temperature during south west monsoon season of 2007-08 ranged between $18.7^{\circ} \mathrm{C}$ to $35.5^{\circ} \mathrm{C}$ at. The water temperature during July and August was low because of heavy rainfall and precipitation. And the recorded high value during summer (April \& May) could be attributed to high solar radiation (Das \& Srivastava, 1956; Karuppasamy and Perumal, 2000; Senthilkumar et al., 2002;Senthilkumar et al., 2002 ).

Dissolved Oxygen: in the present study it was observed that Gourikere pond shows more dissolved oxygen in the month of April $10.8 \mathrm{mg} / \mathrm{l}$ and minimum $6.4 \mathrm{mg} / \mathrm{l}$ in the month of November 2007 is presented in Fig. 4 . The high dissolved oxygen may be attributed to the phytoplanktonic photosynthetic 
Sustainability, Agri, Food and Environmental Research 1(1): 1-7; 2013

ISSN: 0719-3726

activity and in addition temperature and high salinity similar observations were made by various workers on dissolved oxygen productivity and attributed to the water temperature, phytoplankton and degree of pollution (Ganapathi, 1960, Gosh et al., 1974, George et al., 1986).

Hydrogen ion Concentration $(\mathrm{pH})$ : the monthly variation in the hydrogen ion concern in Gourikere pond of different seasons are presented in Fig.5. During north east season 2007-08 at different station varies 8.1 to 9.1 while south west of same year $8.0-9.0$ in summer it ranges 8.6 to 9.00 . In the present study higher concentration of $\mathrm{pH}$ was observed during summer and South West monsoon season could be attributed to enhanced rate of evaporation coupled with human interference are partly to enhanced photosynthetic activity. Maximum pH during summer season also observed by David et. al, (1974), Ayyappan et al (1985), , Vijaykumar \& Paul (1990), They also related the high pH with photosynthetic activity and more conductive for net production.

Free Carbon dioxide $\left(\mathrm{CO}_{2}\right)$ : in present investigation much fluctuation of free $\mathrm{CO}_{2}$ has been observed highest values of free $\mathrm{CO}_{2}$ was observed during $(7.4 \mathrm{mg} / \mathrm{l})$ in December 2007 and February 2008 (12.00 $\mathrm{mg} / \mathrm{l}$ ) and traces of free $\mathrm{CO}_{2}$ in the month of October 2007 predicted (Fig.6). The high free $\mathrm{CO}_{2}$ in this tank be attributed to the high phytoplanktonic photosynthetic activity, high $\mathrm{pH}$, alkalinity and sewage pollution. Traces of free $\mathrm{CO}_{2}$ in a particular months cannot be justified because of high $\mathrm{pH}$, Total Alkalinity and less activity of phytoplankton. On the other hand Schindler (1971) and Cole (1975) conclude that the free $\mathrm{CO}_{2}$ supply rarely limits the growth of phytoplankton.

Nutrients (Nitrate): in present work the nitrate content of Gourikere pond (Fig. 7) Varies form a minimum of $0.69 \mathrm{mg} / \mathrm{l}$ (August 2007) and maximum of $1.30 \mathrm{mg} / \mathrm{l}$ (May 2007). The high content of nitrate in this tank can be attributed to sewage inflow. And also other polluting agents observed similar observation was made by of Venktateshwarlu (1969) have shown that organic pollution increase the nitrogen content of natural water bodies. Munawar (1970) indicated an inverse relation between nitrates and phosphate. Role of nitrate and phosphorus ratio information of blue green algal blooms has been studies by Jayangowdar (1964), Zafar (1967). According to them high nitrate and low phosphate favors the formation of cyanophyccae bloom.

Nutrients (Phosphate phosphorus): in the present investigation it was observed that the minimum phosphate was in the month of July $2007(0.30 \mathrm{mg} / \mathrm{l})$ and maximum in the month of April $(0.46 \mathrm{mg} / \mathrm{l})$ while in December 2007 it is $(0.63 \mathrm{mg} / \mathrm{l})$ in 2007 high phosphate in the pond favours for productivity of phytoplankton as represented (Fig. 8). According to Welch (1952) Hutchinson (1957) and Horne (1978) studies main source of phosphate is sewage. Ganapathi (1960) in tropical water, phosphates are always present in sufficient quantity. In present study the frequent occurrence of cyanophycean blooms in the Gourikere pond attributes to high content of phosphates.

Magnesium: in the present investigation much fluctuation in magnesium content, highest $(88.64 \mathrm{mg} / \mathrm{l})$ values were observed during July 2007 lowest in the month of June 2007 (11.79 mg/l) (Fig.9). Magnesium shows direct relation with the dissolved organic matter. According to Kumar et al. (1994) have correlated total hardness with calcium and magnesium hardness.

Sulphate: in the present investigation it was observed that the fluctuation of sulphate content in Gourikere pond (Fig.10) varies from a minimum of $2.45 \mathrm{mg} / \mathrm{l}$ in the month of February and April 2008 and maximum in the month of $5.16 \mathrm{mg} / \mathrm{l}$ in December 2007. The high level of sulphate content in tank 
Sustainability, Agri, Food and Environmental Research 1(1): 1-7; 2013

ISSN: 0719-3726

generally associated with increased level of pollution increased high level of sulphide during summer is because of activity of biodegradation. Similarly, Vamos (1964) and Ruttner (1953).

Silicate: in the present work it was observed in the Gourikere pond shows maximum silicate in the month of March $(0.585 \mathrm{mg} / \mathrm{l})$ and minimum in the month of July 2007 (0.289 mg/l). Munawar (1970) based on the work on fresh water ponds found direct correlation of silicates with temperature. However, in the present investigation it was not correlated. Atkins (1926) is opinion that increase in silicates is due to increases in $\mathrm{pH}$.

Calcium: calcium is essential for all organisms, begin an important cell wall constituent, calcium direct effect on $\mathrm{pH}$ and carbonate system. In the present investigation it was observed that the minimum calcium was in the month of May 2007 (33.41 mg/l) and maximum in the month of September 2007 $(138.10 \mathrm{mg} / \mathrm{l})$ in Gourikere pond as represented (12).The high content of calcium indicates the high total hardness of this water body in addition carbonates and bicarbonates are also high which are attributed to be increasing the calcium content. Similarly Prasad and Manjula (1980), Swarnalatha and Rao (1998) have observed that the water rich in bicarbonates and carbonates are also rich in calcium (Figure 11).

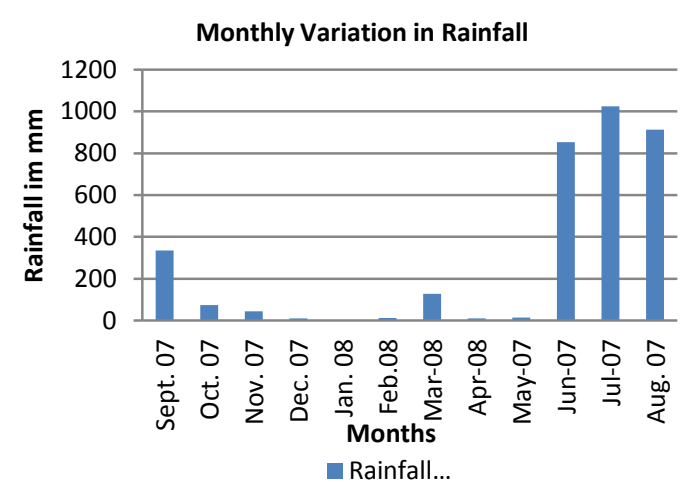

Fig.1 showing monthly variation in rainfall

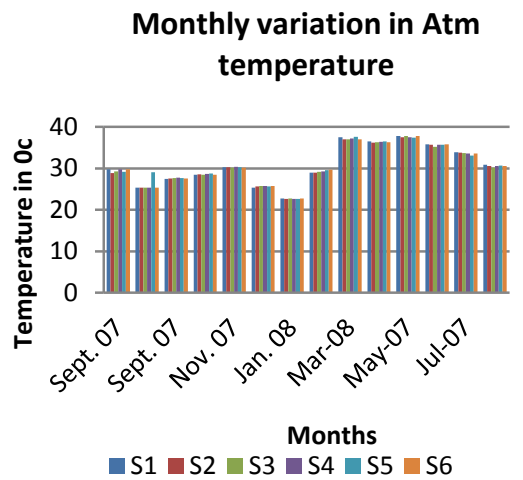

Fig.2 showing monthly variation in Air temperature.
Monthly variation in Water Temperature

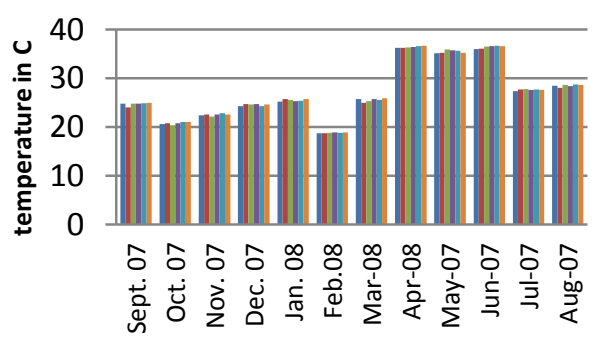

- M1 $\quad$ Months
Monthly variation in dissolved Oxygen

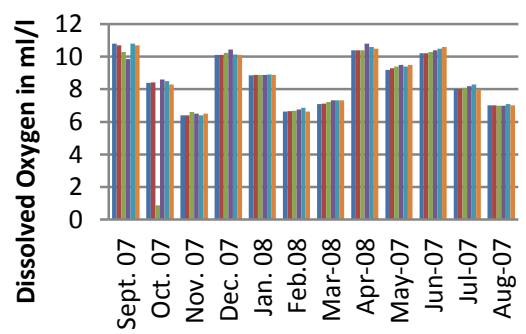

Months

S1 1 S2 S3 $\square$ S4 S5 $\square 6$

Fig. 3 showing monthly variation in water temperature. Fig. 4 Showing Monthly variations in Dissolved Oxygen 


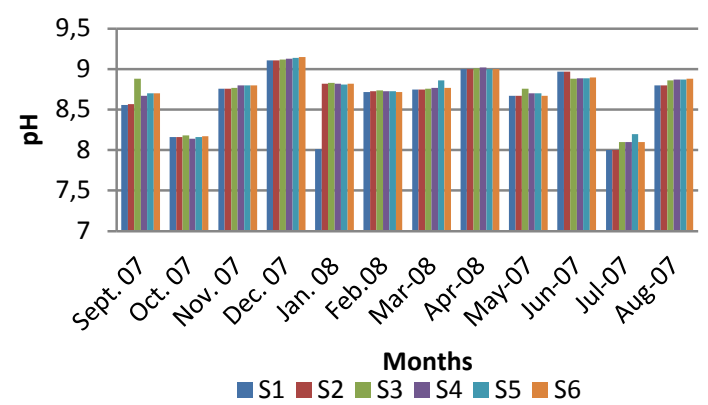

Fig. 5 Showing Monthly variations in $\mathrm{pH}$ $\mathrm{CO}_{2}$

Monthly variation in Nitrate

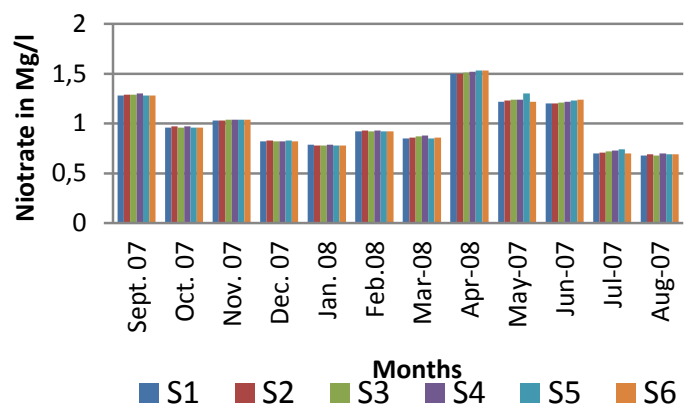

Fig.7 Showing Monthly variations in Nitrate Phosphate

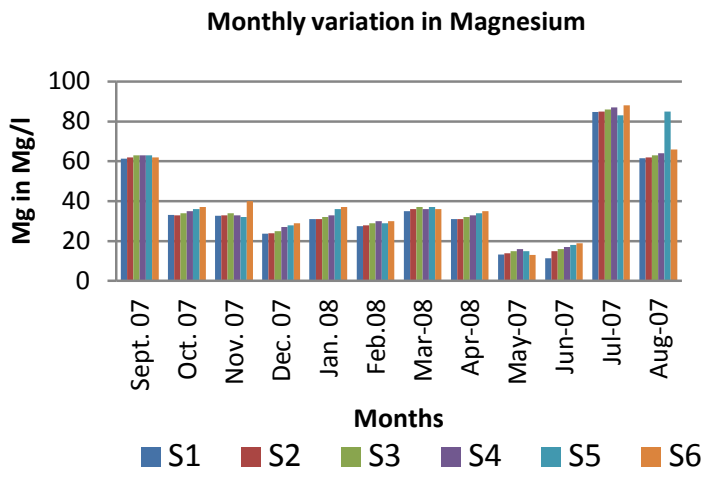

Fig.9 showing Monthly variation in Magnesium Sulphate
Monthly Variation in $\mathrm{CO}_{2}$

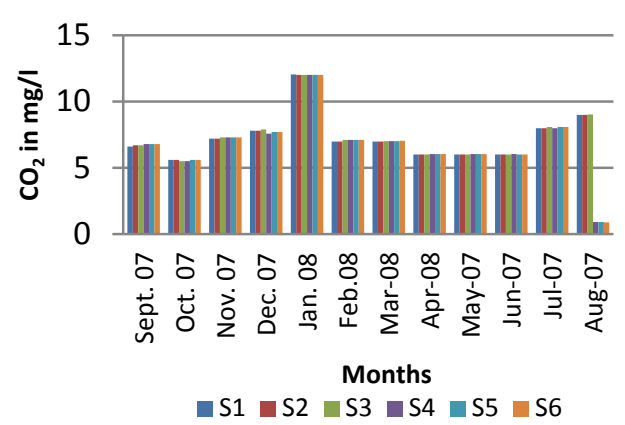

Fig.6 Showing Monthly variations in

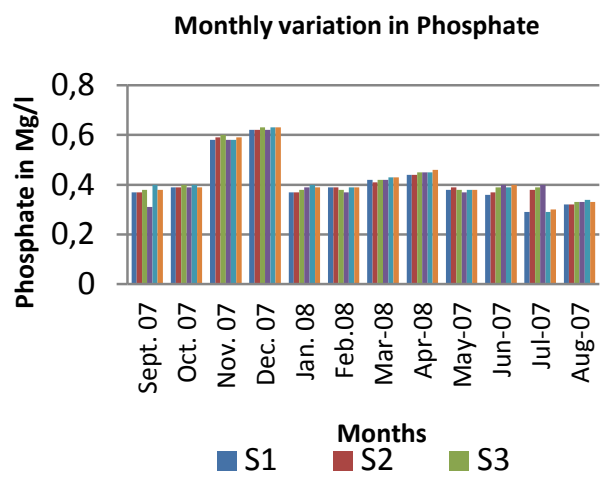

Fig.8 Showing Monthly variations in

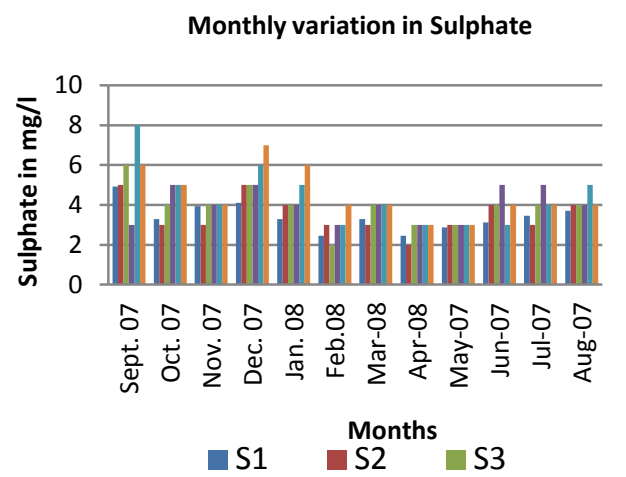

Fig.10 showing Monthly variation in

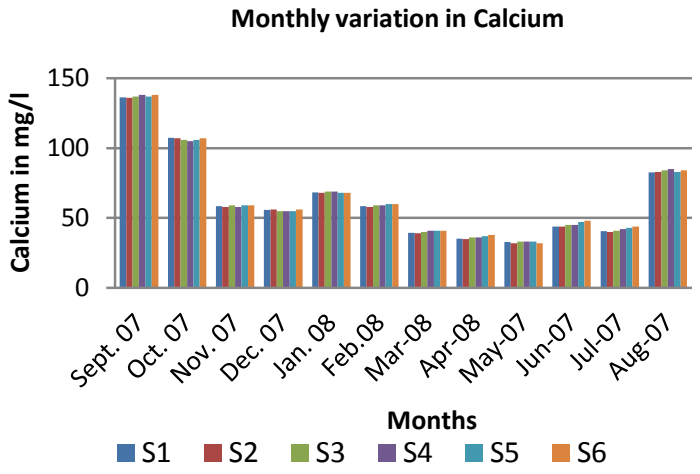

Fig.11 showing Monthly variation in Calcium 
Sustainability, Agri, Food and Environmental Research 1(1): 1-7; 2013

ISSN:

0719-3726

\section{References}

Atkins, W. and R.G. 1926: Seasonal changes in the silica content of natural waters in relation to phytoplankton. Journal of Marine Biological Association U. K. 14: 89-99.

Ayyappan, S. and T. R. C.Gupta, 1985: Limnology of Ramasamudra tank - Primary production. Bulletin Botanical Society, Sagar, 32: 82-88.

Cole, G. A., 1975. Text book of Limnology, Pub. C. V. Mosby, Co., pp. 283.

Das, S. M. and V. K. Srivastava, 1956: Quantitative studies on the freshwater plankton part I, plankton of the fish tank in Lucknow, India. Proceedings of National Academy of Sciences, 26: 82-89.

David, A., Rao, N. G. S. and P. Ray, 1974: Tank fishery resources of Karnataka. Bulletin of Center Inland Fisheries Research Institute, Barrackpore, 20:87.

Ganapathi, S.V. 1960: Ecology of tropical waters. Proc. Symp. Algology. ICAR., New Delhi, PP. 204-218.

George, J.P., Venugobal, G. and G. Venkateshwaran 1986: Anthropogenic eutrophication in a perennial tank: effect on the growth of cyprinus carpio communis. Indian 4. Environental Health. 218: 303-313.

Gosh, A., Rao, L.H and S.C. Banerjee, 1974: Studies of the hydrological condition of a sewage fed pond with a note on their role in fish culture. 4. Inland Fisheries Society India V. PP., 51-61.

Herne, A.J. 1978: Nitrogen fixation in eutrophic lakes. In water pollution microbiology Vol. 2 (Ed. R. Mitchell) John Wiley and Sons. New York. PP.1-30.

Hutchinson, G.E. 1957 : A Treatise on limnology: Geography, Physics and Chemistry. Vol. I, John Wiley and Sons. Inc. (U.S.A), p. 1015.

Jayangowdar, I., 1964. The bioecologicla study of nuggikere lake in Dharwar, Mysore state South India Hydrobiologia 23: 515-532.

Karuppasamy, P.K. and P. Perumal, 2000. Biodiversity of zooplankton at Pichavaram mangroves, South India. Advanced Biosciences, 19: 23-32.

Kumar, H. D., Bisaria, G.P., Bhondari, C.M., Rana, B.C. and V. Sharma, 1994: Ecological studies on algae isolated from the effluent of an oil refinery, a fertilizer factory and a brewary. Indian Journal of Environmental Health 16: 243-255.

Munawar, M. 1970: Limnological studies on freshwater ponds of Hyderabad, India-II. The Biocoenose, distribution of unicellur and colonical phytoplankton in polluted and unpolluted environments. Hydrobiology, 36: 105-128.

Prasad, B.N. and S. Manjula, 1980: Ecological study of blue-green algae in river Gomati, Indian 4. Environmental Health., 22: 151-168. 
Sustainability, Agri, Food and Environmental Research 1(1): 1-7; 2013

ISSN:

0719-3726

Ruttner, F. 1953: Fundamentals of Limnology. Uni. of Toronto Press; Toronto. 242 p.

Schindler, D.W. 1971: Light temperature and oxygen regimes of selected lakes in the experimental lakes area, North West Ontario. 4. Fisheries. Research Board. Canada, 28: 157169.

Senthilkumar, S., P. Santhanam and P. Perumal: Diversity of phytoplankton in Vellar estuary, southeast coast of India. The 5th Indian fisheries forum proceedings (Eds.: S. Ayyappan, J.K. Jena and M. Mohan Joseph). Published by AFSIB, Mangalore and AeA, Bhubanewar, India. pp. 245-248 (2002).

Swarnalatha, N. and A. Narsing Rao, 1998: Ecological studies of Banjara lake with reference to water pollution. Journal of Environmental Biology 19: 179-186.

Vamos, R. 1964: The release of hydrogen sulphide from mud. Journal of Soil Sciences 15: 103109.

Venkateshwaralu, V., 1969: An ecological study of the algae of the river Mossi. Hyderabad, (India) with special reference to water pollution. J. Physico-chemical complex. Hydrobiologia 33:117-143.

Vijaykumar, K. and Paul, R 1990: Physico-chemical studies on the Bhosga Reservoir in Gulbarga. Karnataka. 4. Ecobiology 2: 332-335.

Welch, P.S. 1952: Limnology. McGraw Hill Book Co. INC, New York. 538 p.

Zafar, A. R., 1967: On the ecology of algae in certain fish ponds of Hyderabad, India III-The periodicity Hydrobiologia. 30: 96-112. 